Gut, 1980, 21, 689-694

\title{
Studies on long chain fatty acid:CoA ligase from human small intestine
}

\author{
H BIERBACH* \\ From the II Department of Medicine, University of Mainz, Federal Republic of Germany
}

SUMMARY Long chain fatty acid:CoA ligase (EC 6.2.1.3.) was examined in human small intestinal mucosa using the hydroxamate-trapping method. With optimal assay requirements using palmitate as substrate a significant difference of specific activities could be detected in the total homogenate from duodenum, $40.9 \pm 11.6 \mathrm{nmol} / \mathrm{min}$ per mg protein versus upper jejunum, $51.9 \pm 13 \cdot 7(\mathrm{P}<0.05)$. The enzyme activity of the microsomal fraction of upper jejunum was $101 \cdot 8 \pm 44 \mathrm{nmol} / \mathrm{min}$ per mg protein. ATP, CoA, and $\mathrm{Mg}^{2+}$ were essential constituents of the reaction. A broad pH-optimum was observed between 6.75 and 7.75 with a maximum at a $\mathrm{pH}$ of 7.25 . Whereas palmitate in the presence of albumin revealed a wide range of optimal concentration in supporting maximal enzyme activity, oleate was found to strongly inhibit the reaction. Where substrate specificity with both the total homogenate and the microsomal fraction was concerned, maximal reaction rates were obtained with palmitate for the long chain saturated fatty acids $C_{12: 0^{\prime}} C_{14: 0^{\prime}} C_{16: 0^{\prime}}$ and $C_{18: 0^{\prime}}$ and with oleate for the long chain unsaturated fatty acids $C_{18: 1} \quad C_{18: 2^{\prime}}$ and $C_{18: 3^{\prime}}$ respectively. The highest specific activity of the enzyme was localised in the microsomal fraction. The kinetic data and properties of the long chain fatty acid:CoA ligase from human intestine are discussed with respect to the intestinal enzyme from other species.

Three pathways of triacylglycerol biosynthesis in intestinal mucosa have been well established during the last two decades: the monoglyceride-, the glycerolphosphate- and the dihydroxyacetone phosphate pathway. ${ }^{1}$ The monoglyceride pathway is the quantitatively predominant reaction sequence for intestinal triacylglycerol biosynthesis in the rat, ${ }^{2}$ hamster ${ }^{3}$ and man. ${ }^{4}$ Whereas these three pathways differ with respect to the acyl-acceptor involving 2-monoglyceride, sn-glycerol-3-phosphate, and dihydroxyacetone phosphate respectively, activated long chain fatty acids consisting of their CoAderivatives serve as a common substrate. The enzyme catalysing the activation of long chain fatty acids to their CoA-ester with the formation of a thiolester bond is the long chain fatty acid: CoA ligase (EC 6.2.1.3), a key enzyme in fatty acid metabolism. Equation 1 shows the reaction catalysed by this enzyme: Fatty acid+CoA + ATP $\leftrightharpoons$ Fatty acyl-CoA + AMP + PPi .

† Inorganic pyrophosphate.

*Address for correspondence: Dr H Bierbach, II Department of Medicine, University of Mainz, Langenbeckstr. 1, D-6500 MAINZ 1, Federal Republic of Germany.

Received for publication 11 March 1980
First demonstrated in guinea-pig liver by Kornberg and Pricer, ${ }^{5}$ this enzyme was subsequently shown to occur in the small intestinal epithelium of several species-that is, rabbit, ${ }^{6}$ rat, $^{7-10}$ pig, ${ }^{11}$ guinea-pig and cat. ${ }^{1}$ Although indirect evidence exists for the activity of fatty acid: CoA ligase in the human intestine from studies of triacylglycerol biosynthesis, ${ }^{12} 13414$ this enzyme has not been directly determined in the intestinal mucosa of man. Thus the purpose of this study was to describe optimal kinetic conditions, to demonstrate the substrate specificity using long chain saturated and unsaturated fatty acids and to reveal the intracellular distribution of the long chain fatty acid:CoA ligase from human small intestine.

\section{Methods}

Multiple histologically normal biopsies were obtained from the pars descendens duodeni of patients who had an oesophagogastroduodenoscopy for different indications, after an overnight fast usually between 9.00 and 12.00 a.m. Informed consent was obtained from all individuals. The biopsies were stored at $-20^{\circ} \mathrm{C}$ and analysed within 14 days. This material 
served to obtain normal values for the fatty acid:CoA ligase. For all other purposes mucosal material was gained from resected parts of the duodenum and the proximal jejunum of patients operated for peptic ulcer disease, carcinoma of the stomach or pancreas, and chronic pancreatitis. Immediately after removal, the resected parts of intestine were transferred to ice-cold $0.9 \% \mathrm{NaCl}$. Subsequently the macroscopically normal mucosa was scraped off with the aid of tweezers. Biopsies and mucosal scrapings were homogenised in ice-cold $0.9 \% \mathrm{NaCl}$ using a Potter S-homogeniser (Braun Melsungen Germany) at $600 \mathrm{rpm}$. Protein was determined by the method of Lowry et al..$^{15}$ using bovine serum albumin as standard.

The fatty acid:CoA ligase assay was based on the hydroxamate-trapping method of Kornberg and Pricer (1953) as slightly modified by Rodgers et al. ${ }^{16}$ and followed under optimally determined conditions. The principle of the hydroxamate method is based on the formation of red complex salts when hydroxamates react with ferric chloride. In the fatty acid: CoA ligase assay hydroxamic acid derives from the reaction of the thiolester acyl-CoA with hydroxylamine. Unless otherwise stated, the standard assay system contained, in a final volume of $2.0 \mathrm{ml}$, the following concentrations of substances in the order given: a $\mathrm{NH}_{2} \mathrm{OH}$-Tris buffer of $\mathrm{pH} \mathbf{7 \cdot 2 5}$ to provide for $1.0 \mathrm{M} \mathrm{NH}_{2} \mathrm{OH}$ and $0.1 \mathrm{M}$ Tris; $10 \mathrm{mM} \mathrm{MgCl}_{2}$, $1.5 \mathrm{mM} \mathrm{CoA}, 3.0 \mathrm{mM}$ dithiothreitol, $10.0 \mathrm{mM}$ ATP, $6.0 \mathrm{mM}$ palmitic acid, and $20 \mathrm{mg} / \mathrm{ml}$ bovine serum albumin. Palmitic acid was dissolved in a small volume of $96 \%$ ethanol (final volume in the test $0.04 \mathrm{ml}$ ) and vigorously mixed with the albumin solution. Oleic acid was treated similarly but used at a concentration of $2.0 \mathrm{mM}$. After preincubation at $37^{\circ} \mathrm{C}$ for five minutes, the reaction was started with the addition of mucosal homogenate or microsomes in appropriate amounts, and the contents were incubated at $37^{\circ} \mathrm{C}$ for 15 minutes. A control lacking ATP was always included as a blank for each sample.

The reaction was terminated by the addition of $2.0 \mathrm{ml} 96 \%$ ethanol and $0.4 \mathrm{ml} 6.0 \mathrm{M} \mathrm{HCL}$. Then $15.0 \mathrm{ml}$ light petroleum (b.p. $40-60^{\circ} \mathrm{C}$ ) were added and the contents of each stoppered tube vigorously agitated for one minute. After separation of the two layers, $12 \mathrm{ml}$ of the light petroleum phase were removed, taken to dryness by a rotation evaporator, and the residue redissolved in $1.0 \mathrm{ml}$ chloroform-ethanol (1:1, by vol.). The iron-hydroxamate complex was developed by the addition of $2.0 \mathrm{ml} \mathrm{4} \%$ Hill's solution $A^{17}$ freshly diluted from the stock solution with chloroform-ethanol $(1: 1$, by vol.). After 20 minutes, the absorbance was measured at $520 \mathrm{~nm}$. A molar extinction coefficient of the iron-hydroxamate complex of $1.0 \times 10^{2} 1 \times \mathrm{mmol}^{-1} \times$ $\mathrm{mm}^{-1}$, as calculated by Kornberg and Pricer, ${ }^{5}$ was used. Specific activity was expressed as nmol product formed $/ \mathrm{min}$ per $\mathrm{mg}$ protein.

Subcellular fractionation of human intestinal mucosa was performed according to the method of Hübscher et al. ${ }^{18}$ As marker enzymes of the mitochondrial and microsomal fractions the succinic dehydrogenase with cytochrome $c$ as electron acceptor $^{19}$ and the glucose-6-phosphatase, ${ }^{19 \mathrm{a}}$ respectively, were assayed.

\section{Results}

The optimal assay conditions were determined in the whole homogenate using palmitic acid as substrate. Maximal palmitate activation was found to occur with concentrations of ATP above $5.0 \mathrm{mM}$, CoA above $1.0 \mathrm{mM}$, and $\mathrm{MgCl}_{2}$ above $5.0 \mathrm{mM}$, and hence concentrations of $10.0 \mathrm{mM}, 1.5 \mathrm{mM}$, and $10.0 \mathrm{mM}$ respectively, were chosen for subsequent experiments. Addition of ATP, CoA, and $\mathrm{MgCl}_{2}$ was essential for the formation of palmitoylCoA with the subsequent development of hydroxamate. Maximum reaction rates were reached with $0.1 \mathrm{M}$ Tris and between 1.0 and $1.5 \mathrm{M}$ hydroxylamine.

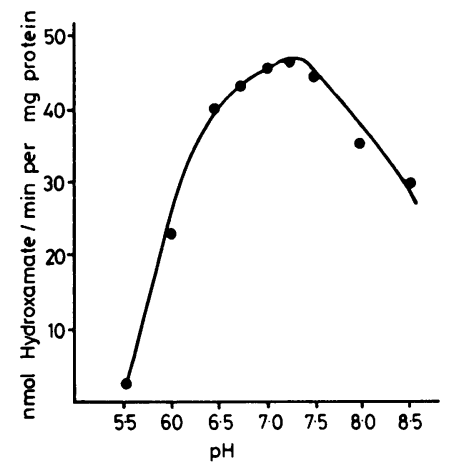

Fig. 1 pH-optimum of long chain fatty acid:CoA ligase using palmitate as substrate under standard assay conditions with total homogenate as enzyme source. Hydroxylamine-Tris served as buffer.

The $\mathrm{pH}$ optimum in this reaction system was spread between 6.75 and 7.75 with a maximum at $7 \cdot 25$ (Fig. 1) which was used for additional studies. Under these optimal assay conditions, using whole homogenate as the source of enzyme, the rate of activation was proportional to the period of incubation and the amount of protein. As shown in Fig. 2, there was a linear relationship between enzyme activity and the duration of incubation over 


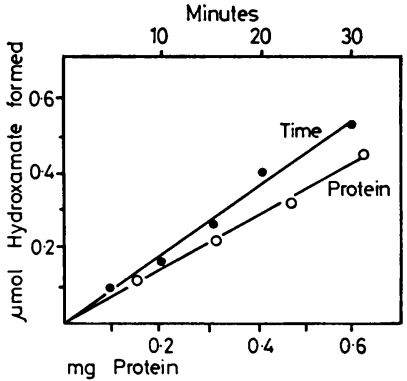

Fig. 2 Linearity of long chain fatty acid:CoA ligase assay with protein and time. Assays with total homogenate were performed as described in the Methods section as a function of protein or time with $0.51 \mathrm{mg}$ of protein. The amount of protein shown on the abscissa is given as $m g$ protein per assay.

a period of 30 minutes and the amount of protein up to $0.6 \mathrm{mg}$ per assay. Using microsomes as the enzyme source the reaction rate was linear up to $0.2 \mathrm{mg}$ of protein per assay (not shown). Whole homogenate boiled for five minutes revealed no enzyme activity. KF did not activate long chain fatty acids in human mucosa at concentrations up to $10.0 \mathrm{mM}$. This was in accord with the behaviour of fatty acid:CoA ligase in rat intestine. ${ }^{16}$ Furthermore, fluoride added to the incubation medium at a concentration of $50.0 \mathrm{mM}$ lowered palmitate activation by $90 \%$.

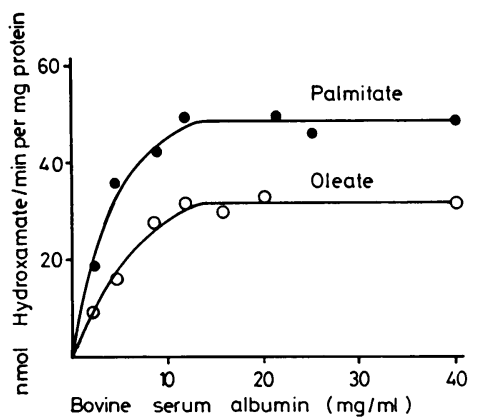

Fig. 3 Dependence of the long chain fatty acid:CoA ligase activity on bovine serum albumin concentration. Total homogenate was used as enzyme and standard assays were performed as described in the Methods section.

Next, the influence of various concentrations of albumin on hydroxamate formation was investigated. As shown in Fig. 3 albumin essentially increased the enzyme activity, reaching a plateau at $12 \mathrm{mg} / \mathrm{ml}$ when both palmitic and oleic acid were used as substrate. No inhibition was observed at concentrations of BSA up to $40 \mathrm{mg} / \mathrm{ml}$ and thus a

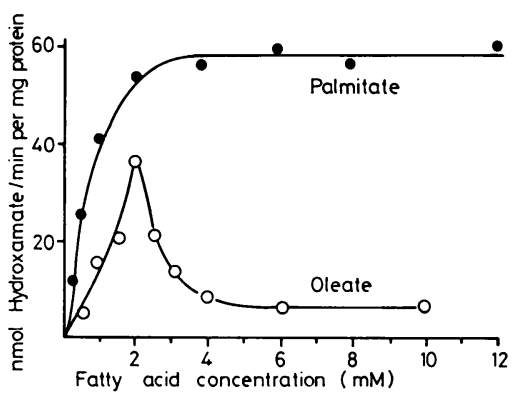

Fig. 4 Dependence of the long chain fatty acid:CoA ligase activity on the fatty acid concentration. Standard assay conditions were used with the total homogenate as enzyme source.

BSA-concentration of $20 \mathrm{mg} / \mathrm{ml}$ reaction mixture was chosen for further experiments. With the whole homogenate as enzyme source, optimal palmitate concentrations were noted above $4.0 \mathrm{mM}$ (Fig. 4) with no change in the reaction rate occurring up to $12.0 \mathrm{mM}$. In contrast, a marked difference was observed when oleic acid was used as substrate. As demonstrated in Fig. 4, enzyme activity was maximal only at an oleic acid concentration of $2.0 \mathrm{mM}$. At higher levels oleate was markedly inhibitory. Analogous results of palmitate and oleate activation were obtained when microsomes were used as the enzyme source. Optimum amounts for the saturated fatty acids $C_{12: 0}, C_{14: 0}$, and $\mathrm{C}_{18: 0}$ were identical with those for palmitate and

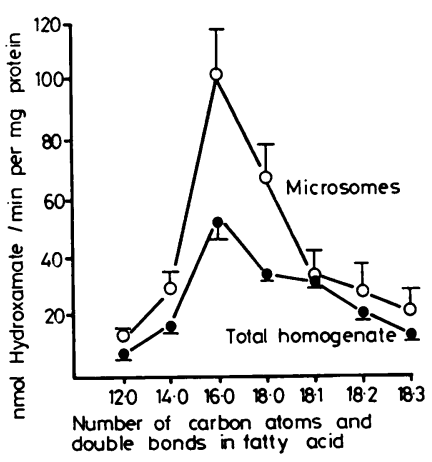

Fig. 5 Substrate specificity of long chain fatty acid:CoA ligase. Assays were performed as described in the Methods section using total homogenate and microsomes as enzyme source. Saturated long chain fatty acids had a final concentration of $6.0 \mathrm{mM}$, unsaturated long chain fatty acids a final concentration of $2.0 \mathrm{mM}$. Mean values $\pm S E M$ were given for nine experiments (total homogenate) and for seven experiments (microsomes). 
the unsaturated fatty acids $C_{18: 2}$ and $C_{18: 3}$ with those found for oleate (not shown). For subsequent assays, concentrations of $6.0 \mathrm{mM}$ and $2.0 \mathrm{mM}$ were chosen for saturated and unsaturated fatty acids, respectively.

With optimal assay conditions available, the fatty acid specificity of the enzyme was determined with various long chain saturated and unsaturated fatty acids. As seen in Fig. 5, the pattern of reaction rates was similar for both enzyme sources. Setting the specific activity of laurate activation as 100 , the relative rates of activation of myristate, palmitate, stearate, oleate, linoleate, and linolenate were respectively, 203: 697: 459: 228: 195: 147 for the microsomal fraction and $210: 625: 412: 383$ : 253: 165 for the total homogenate. Thus, maximum reaction rates were observed with palmitate for the saturated and with oleate for the unsaturated fatty acids. With respect to the enzyme source, oleate activation was markedly less in the microsomal fraction than in the total homogenate.

Table Subcellular distribution of long chain fatty acid:CoA ligase in mucosa of human small intestine

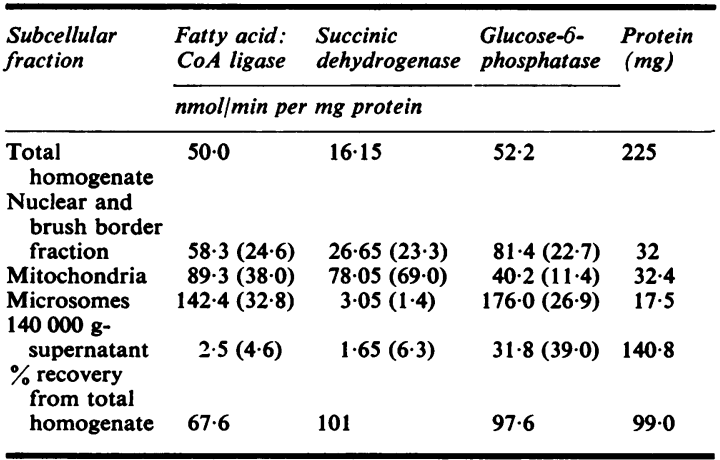

Subcellular fractions of intestinal mucosa were prepared and enzymes assayed as described in the Methods section. The percentage of the total activity recovered is shown in parentheses. Specific activities are expressed as nmol product formed/min per $\mathrm{mg}$ protein.

The Table presents the data for a typical experiment of the subcellular fractionation and distribution of long chain fatty acid:CoA ligase from human small intestinal mucosa. From these data it is evident that the highest specific activity of this enzyme was found in the microsomal fraction, followed by the mitochondrial and the nuclear and brush border fractions. With regard to the distribution of total activity it can be seen that the fatty acid:CoA ligase was equally associated with the mitochondrial, microsomal, and the nuclear and brush border fractions. This might be partially due to the contamination of the mitochondrial and the nuclear and brush border fractions with microsomes, as can be seen by the distribution of glucose-6-phosphatase, a microsomal marker enzyme.

The rate of fatty acid:CoA ligase activity with palmitate as substrate was determined in the total homogenate of biopsies from the pars descendens duodeni of 27 humans and in the total homogenate of the mucosa of nine resected human upper jejunal segments. The mean enzyme activity from upper jejunum was significantly higher than from the duodenum, $51.9 \pm 13.7$ (1 SD) $\mathrm{nmol} / \mathrm{min}$ per $\mathrm{mg}$ protein versus $40.9 \pm 11.6(\mathrm{P}<0.05)$. A mean \pm 1 SD of $101 \cdot 8 \pm 44.0 \mathrm{nmol} / \mathrm{min}$ per $\mathrm{mg}$ protein was found for microsomal fractions derived from the upper jejunal mucosa of seven patients.

\section{Discussion}

The present investigation of long chain fatty acid: CoA ligase clearly demonstrated this enzyme in the mucosa of human small intestine. Specific activity in the total homogenate of duodenal mucosa, $40.9 \mathrm{nmol} / \mathrm{min}$ per $\mathrm{mg}$ protein, at $37^{\circ} \mathrm{C}$ using palmitate as substrate found by us was considerably higher than that reported by Senior and Isselbacher ${ }^{7}$ for rat mucosa $(1.4 \mathrm{nmol} / \mathrm{min}$ per $\mathrm{mg}$ protein), by Pande and $\mathrm{Mead}^{20}$ in rat mucosa $(0.7 \mathrm{nmol} / \mathrm{min}$ per $\mathrm{mg}$ protein), and by Brindley and Hübscher ${ }^{1}$ in cat mucosa $(22 \mathrm{nmol} / \mathrm{min}$ per $\mathrm{mg}$ protein). Comparable specific activities in the total homogenate of rat jejunal mucosa were found by Rodgers et al. (1972) who measured an activity of about $37 \mathrm{nmol} / \mathrm{min}$ per $\mathrm{mg}$ protein, also using the hydroxamate-trapping method. With microsomes from the upper jejunum as enzyme source, similar specific activities were detected by Rodgers and Bochenek ${ }^{9}$ in the rat $(119 \mathrm{nmol} / \mathrm{min}$ per $\mathrm{mg}$ protein) and by us in man $(102 \mathrm{nmol} / \mathrm{min}$ per $\mathrm{mg}$ protein). The data of the present report showed a significantly higher activity of palmitate-activating enzyme in the total homogenate from upper jejunum versus duodenum. In rats, a similar finding was reported by Rodgers and Bochenek ${ }^{9}$ for the microsomal fatty acid-CoA ligase, $119 \pm 26 \mathrm{nmol} / \mathrm{min}$ per $\mathrm{mg}$ protein from the upper jejunum versus $106 \pm 20$ from the duodenum, though this difference was not significant. The possible reason for this physiological difference in man may be due to the fact that the proximal small bowel is the maximal absorptive site for products of triacylglycerol hydrolysis-that is, 2-monoglycerides and long chain fatty acids. Thus the greater enzyme activity in the upper jejunum may be the consequence of enzyme induction by the natural substrates long chain fatty acids, ${ }^{9}$ which might be present in higher concentrations in the upper jejunum than in the pars descendens duodeni. 
The kinetic data of the palmitate-activating enzyme from the human small intestine showed many similarities with those reported by Pande and Mead $^{8}$ for the rat liver and by Rodgers et al. ${ }^{16}$ for the rat small intestine. Optimal concentrations of substrates and cofactors were found for the most part to be within the same range. Fluoride caused no stimulatory effect, as observed for the enzyme from rat liver ${ }^{8}$ and, as an inhibition was achieved with a concentration greater than $10.0 \mathrm{mM}$, it was omitted from the assay. Bovine serum albumin, which markedly stimulated palmitate and oleate activation, was shown to be effective over a broad range up to $40 \mathrm{mg} / \mathrm{ml}$ in the total homogenate of human mucosa as opposed to microsomes from rat liver $^{8}$ and to the 14-fold purified enzyme from rat liver (Bar-Tana et al., 1971). With the two latter enzyme preparations albumin was effective within a narrow concentration range only and became profoundly inhibitory over this limit. Albumin at low concentrations stimulated enzyme activity, presumably because of lowering the free concentration of the fatty acids, whereas albumin at high concentrations was inhibitory, presumably because of competition with the enzyme for the fatty acid substrate. $^{21}$ However, the mechanism by which albumin stimulated the fatty acid-CoA ligase is unknown. The addition of CoA, ATP and $\mathrm{Mg}^{2+}$ was essential for acyl-CoA formation, as no value above the blank was observed without the addition of these agents.

The optimal requirements of long chain saturated and unsaturated fatty acids for the human intestinal enzyme were comparable with the findings of Brindley and Hübscher ${ }^{1}$ for the intestinal enzyme of the guinea-pig and of Rodgers et al. ${ }^{16}$ for that of the rat. In the presence of bovine serum albumin long chain saturated fatty acids $C_{12: 0}, C_{1: 40}, C_{16: 0}$ and $C_{18: 0}$ showed a wide range of optimal concentrations in supporting maximal enzyme activity. In contrast, the unsaturated long chain fatty acids $C_{18: 1}, C_{18: 2}$ and $C_{18: 3}$ exhibited a marked substrate inhibition with a narrow range of optimal concentration at $2.0 \mathrm{mM}$. The reason for this profound inhibition above $2.0 \mathrm{mM}$ is so far unknown.

The substrate specificity of the enzyme from the total homogenate and the microsomal fraction was similar except for oleate. Using the total homogenate as enzyme source, the relative activity was markedly higher than in the microsomal fraction, which might be due to the fact that the substrate inhibition by oleate-and to a lesser degree by linoleate and linolenate-was overcome by the higher protein content of the total homogenate than that of the microsomal fraction. The substrate specificity of long chain fatty acid:CoA ligase from the small intestine varies significantly from one species to another. Maximal reaction rates were observed in pig intestinal mucosa ${ }^{11}$ in guinea-pig and cat intestinal microsomes ${ }^{1}$ with laurate, myristate, and palmitate, respectively. No data of relative activities concerning the enzyme of rat small intestine were available, although high reaction rates were demonstrated with linoleate, oleate, and palmitate in the order mentioned. ${ }^{16}$ Where the fatty acid specificity profile of the human intestinal enzyme is concerned, the greatest accordance exists with the intestinal preparations from the cat. In both human and cat intestinal mucosa the highest activities were observed with palmitate for the saturated and oleate for the unsaturated fatty acids. From the results of this investigation it cannot be decided whether there are two different enzymes, as has been suggested for rat liver, catalysing the activation of long chain saturated and unsaturated fatty acids, respectively. ${ }^{8}$

As concluded by Brindley,22 the predominant site of triacylglycerol biosynthesis in the intestine is the endoplasmic reticulum. This conclusion was based on several studies which demonstrated the presence of fatty acid:CoA ligase and the enzymes of the monoglyceride- and glycerolphosphate pathway mainly in the microsomal fraction. In agreement with these findings was the subcellular distribution of the human gut fatty acid-CoA ligase, whose highest specific activity was recovered in the microsomal fraction. The detection of the enzyme in the mitochondrial and the nuclear and brush border fractions could be mainly accounted for by contamination with microsomes. Recently, the palmitic acid:CoA ligase of rat small intestine was shown to be far more active in villi than in crypts. ${ }^{23}$ This special localisation in accordance with a similar distribution of the monoacylglycerol acyltransferase and the glycerolphosphate acyltransferase emphasises the importance of this enzyme in triacylglycerol biosynthesis in the small intestine. The detection of long chain fatty acid:CoA ligase in the human gut and the description of optimal kinetic requirements could be used as an interesting tool to study triacylglycerol synthesis in the human intestinal mucosa under various pathological conditions.

The author gratefully acknowledges the expert technical assistance of Mrs Th Wieser and the helpful cooperation of the medical staff, especially Dr H Brünner, from the Surgical Department, University of Mainz, in supplying resected material of the small intestine. 


\section{References}

${ }^{1}$ Brindley DN, Hübscher G. The effect of chain length on the activation and subsequent incorporation of fatty acids into glycerides by the small intestinal mucosa. Biochim Biophys Acta 1966; 125: 92-105.

${ }^{2}$ Mattson FH, Volpenhein RA. The digestion and absorption of triglycerides. J Biol Chem 1964; 239: 2772-7.

${ }^{3}$ Kern F, Jr, Borgström B. Quantitave study of the pathways of triglyceride synthesis by hamster intestinal mucosa. Biochim Biophys Acta 1965; 98: 520-31.

${ }^{4}$ Kayden HJ, Senior JR, Mattson FH. The monoglyceride pathway of fat absorption in man. $J$ Clin Invest 1967; 46: 1695-1703.

${ }^{5}$ Kornberg A, Pricer WE Jr. Enzymatic synthesis of the coenzyme A derivatives of long chain fatty acids. J Biol Chem 1953; 204: 329-43.

${ }^{6}$ Clark B, Hübscher G. Biosynthesis of glycerides in the mucosa of the small intestine. Nature 1960; 185: 35-7.

'Senior JR, Isselbacher KJ. Activation of long chain fatty acids by rat-gut mucosa. Biochim Biophys Acta 1960; 44: 399-400.

${ }^{8}$ Pande SV, Mead JF. Long chain fatty acid activation in subcellular preparations from rat liver. J Biol Chem 1968; 243: 352-61.

${ }^{9}$ Rodgers JB, Bochenek W. Localisation of lipid reesterifying enzymes of the rat small intestine. Effects of jejunal removal on ileal enzyme activities. Biochim Biophys Acta 1970; 202: 426-35.

${ }^{10}$ Dejong JW, Hülsmann WC. A comparative study of palmitoyl-CoA synthetase activity in rat liver, heart and gut mitochondrial and microsomal preparations. Biochim Biophys Acta 1970; 197: 127-35.

1 'Ailhaud G, Sarda L, Desnuelle P. Formation d'hydroxamates d'acides gras à longes chaînes par une fraction subcellulaire de muqueuse intestinale. Biochim Biophys Acta 1962; 59: 261-72.

${ }^{12}$ Dawson AM, Isselbacher KJ. The esterification of palmitate-1- $\mathrm{C}^{14}$ by homogenates of intestinal mucosa. $J$ Clin Invest 1960; 39: 150-60.

${ }^{13}$ Brice RS, Owen EE, Tyor MP. Amino acid uptake and fatty acid esterification by intestinal mucosa from patients with Whipple's disease and non-tropical sprue. Gastroenterology 1965; 48: 584-92.

${ }^{14}$ Sueur R, Cerf M, Di Costanzo G, Debray C. Quantitative studies in vitro on uptake and esterification of palmitate into human and rat jejunal mucosa. Digestion 1977; 15: 34-42.

${ }^{15}$ Lowry OH, Rosebrough NJ, Farr AL, Randall RJ. Protein measurement with the Folin phenol reagent. $J$ Biol Chem 1951;193: 265-75.

${ }^{16}$ Rodgers JB, Jr Tandon R, Fromm H. Acyl-CoA synthetase for long chain fatty acids in rat small bowel and the influence of diets containing different compositions of fatty acids on intestinal lipid reesterifying enzyme activities. Biochim Biophys Acta 1972; 270: 453-62.

${ }^{17}$ Hill UT. Colorimetric determination of fatty acids and esters Anal Chem 1947; 19: 932-33.

${ }^{18}$ Hübscher G, West GR, Brindley DN. Studies on the fractionation of mucosal homogenates from the small intestine Biochem $J$ 1965; 97: 629-42.

${ }^{19} \mathrm{Green}$ DE, Mii S, Kohout PM. Studies on the terminal electron transport system. I. Succinic dehydrogenase. J Biol Chem 1955; 217: 551-67.

${ }^{19 a}$ Baginski ES, Foa PP, Zak B. Glucose-6-phosphatase. In: Bergmeyer $\mathrm{HU}$, ed. Methoden der enzymatischen Analyse 2. Aufl., Band I, Weinheim Verlag Chemie: $1970 ; 830-43$.

${ }^{20}$ Pande SV, Mead JF. Distribution of long chain fatty acid-activating enzymes in rat tissues. Biochim Biophys Acta 1968; 152: 636-8.

${ }^{21}$ Bar-Tana J, Rose G, Shapiro B. The purification and properties of microsomal palmitoyl-coenzyme A synthetase. Biochem J 1971; 122: 353-62.

${ }^{22}$ Brindley DN. The intracellular phase of fat absorption. In: Smyth DH, ed. Biomembranes, vol. 4B: Intestinal absorption. London-New York: Plenum Press, 1974; 621-71.

${ }^{23} \mathrm{Hülsmann}$ WC, Kurpershoek-Davidov R. Topographic distribution of enzymes involved in glycerolipid synthesis in rat small intestinal epithelium. Biochim Biophys Acta 1976; 450: 288-300. 